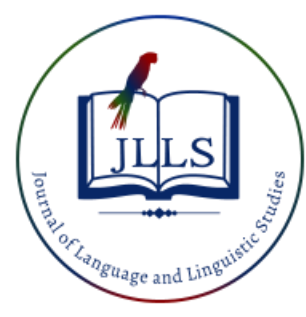

Available online at www.jlls.org

JOURNAL OF LANGUAGE AND LINGUISTIC STUDIES

ISSN: $1305-578 \mathrm{X}$

Journal of Language and Linguistic Studies, 17(1), 662-674; 2021

\title{
The discursive strategies used by Langston Hughes in the construction of whiteness and blackness
}

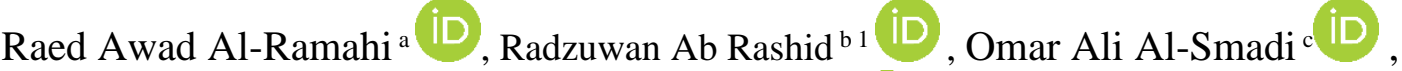 \\ Hanita Hanim Ismail ${ }^{\text {d }}$ iD
}

${ }^{a}$ The University of Jordan, Amman, Jordan ${ }^{b}$ Universiti Sultan Zainal Abidin, Terengganu, Malaysia ${ }^{c}$ Al-Ghad International Colleges for Applied Medical Sciences, Al-Madinah Al-Munawrah, Saudi Arabia ${ }^{d}$ Universiti Kebangsaan Malaysia, Selangor, Malaysia

\section{APA Citation:}

Al-Ramahi, R. A., Rashid, R. A., Al-Smadi, O. A., \& Ismail, H. H. (2021). The discursive strategies used by Langston Hughes in the construction of whiteness and blackness. Journal of Language and Linguistic Studies, 17(1), 662-674. Doi: 10.52462/jlls.45 Submission Date:28/12/2020

Acceptance Date:03/03/2021

\begin{abstract}
This article seeks to identify the main discursive strategies employed by Langston Hughes in constructing entities, people's images and entire social reality in his poetic discourse. More specifically, this article examines how the discursive strategies contribute to the construction of whiteness and blackness. Data was generated from sixty purposively selected Hughes' poems, which were analysed using thematic analysis and Van Dijk's critical discourse analysis. Van Dijk's CDA was selected as a theoretical framework in this study as it draws knowledge from several fields, including sociology, psychology, politics and economics, which contribute to deepening the insights of this study. The analysis of data revealed that Hughes constantly constructs whiteness and blackness through four discursive strategies, which are actor description, resource description, self-identity descriptions and norm and value descriptions. The findings also show that these strategies contribute to the construction of whiteness and blackness by means of highlighting the positive-self and negative other-representations as well as the power relations between Whites and Blacks. It is hoped that this study deepens the understanding of Hughes' poetic discourse and adds novel insights into whiteness and blackness in the American context.
\end{abstract}

Keywords: discursive strategies; whiteness; blackness; Langston Hughes; critical realism; critical studies

\section{Introduction}

Hughes' poetic discourse articulates ideologies related to the cultural constructs of whiteness and blackness. The discursive strategies employed in Hughes' poetic discourse that contribute to constructing these constructs have not yet received sufficient attention from scholars in the field. Previous studies on Hughes' poetry have mainly been concerned with interpreting the racial ideologies and Blacks' suffering (e.g. Sharma, 2017; Stephane, 2017; Muslih, 2016; Reddy, 2013; Poongodi, 2012). These culture-based studies interpreted the ideologies emerging in Hughes' poetry thematically without examining the discursive strategies that contribute to constructing them.

\footnotetext{
${ }^{1}$ Corresponding author.

E-mail address: radzuwanrashid@unisza.edu.my
} 
The majority of prior research has adopted literary analyses (e.g. Gohar, 2007). Some scholars, moreover, conducted linguistic analysis while examining the stylistic features existing in this poetry (e.g. Abed \& Mohammed, 2015; Sharma, 2018). The linguistic analysis provided by CDA highly contributes to enriching the ideological analysis of this study. CDA is also of high significance to this study as it is interdisciplinary in nature. It views language as a social practice, which helps interpreting the social reality emerging in Hughes' poetic discourse.

\subsection{Literature review}

\subsubsection{Whiteness}

The 'whiteness' construct is elusive and its definition has not yet been settled. It is habitually the invisible default (Case, 2012). Whiteness is continually connected to privilege in American cultural context as it is regarded as "a location of structural advantage" (Frankenberg, 1993, p.1). It is also linked to white privilege framework (McIntosh, 1988), which makes it commonly identified as a set of choices advantaging Whites. McIntosh (1988) views whiteness as a racial identity, which advantages Whites in the United States of America as it opens the doors for them in all walks of life, including travelling, schooling and housing. While Frankenberg (1993) and McIntosh (1988) interpret whiteness as an advantage with a wide range of choices, Bhabha (1998) suggests that whiteness has a deep connection to race and racism, and thus whiteness helps maintaining the racist system. In this vein, white supremacy, which is deeply related to whiteness, is regarded as an exact description of every day experience of racism (Cole, 2009). Samaj's (1981) interpretation of whiteness is attached to agency as the discourse of whiteness presumes the Whites' right of agency and the denial of others' agency. The latter interpretation helps drawing attention to the supremacy of whiteness though other interpretations help in this regard. Indeed, the existence of multi interpretations of whiteness evidences that this racial category is subtle.

\subsubsection{Blackness}

In the American cultural context, the 'blackness' construct is also slippery for the reason that "it transforms into something else and travels into another direction" (Johnson, 2003, p.4). Close to whiteness, this construct has been interpreted in several ways. Blackness is biologically and socially construed. As interpreted by Fanon (1986), blackness is allied to black skin, which has created the inferiority of Black people's identity. Like Fanon (1986), Yancy (2008) emphasizes that blackness is usually reduced to the level of body, and thus Blacks' bodies and experiences are objectified. Johnson (2003), on the other hand, associates blackness with slavery, colonialism, racism or the opposite of whiteness (Johnson, 2003). Johnson's (2003) interpretation of blackness is consistent with Mapedzahama and Kwansah-Aidoo's (2017) view of blackness as "a social construct persistently conceived of as an opposition to whiteness" (p.1). Marriot (2007) relates the stereotyping and excluding of blackness to whiteness ideologies, which reveals the depth of relation between both constructs 'whiteness' and 'blackness'.

\subsection{Research questions}

This study seeks to answer the following research questions:

i) What are the discursive strategies deployed in Hughes' poetic discourse?

ii) How do the discursive strategies contribute to the construction of whiteness and blackness?

iii) How do the discursive strategies contribute to the construction of power relations between Whites and Blacks?

\section{Theoretical framework}

Van Dijk's critical discourse analysis is the theoretical framework that steers the analysis in this study. Critical discourse analysis is defined as a discourse analytic approach which centres on how social power, dominance and inequality are enacted, reproduced and resisted in text and talk in the social and 
political contexts where they occur (Van Dijk, 2001). Thus, CDA's critical analysis raises awareness regarding the strategies employed in constructing, maintaining and reproducing (a) symmetrical relations of power as enacted by means of discourse (Van Dijk, 1997). Van Dijk (1995a) points out that discourse analysis is ideological analysis, highlighting that "any property of discourse that expresses, establishes, confirms or emphasizes a self- interested group opinion, perspective or position, especially in a broader socio-political context of social struggle, is a candidate for special attention in such an ideological analysis" (pp.22-23). His framework for ideological analysis includes the following elements: social analysis, cognitive analysis, and discourse analysis. First, the social analysis examines the social structure. Then, the cognitive analysis is an analysis of those properties of discourse that are considered cognitive concepts, such as various types of mental representations. Finally, the discourse analysis is mainly based on text (syntactic features, lexicalization, semantics, and themes) (Van Dijk, 1995b). Though Van Dijk's framework is useful for the analysis of political discourse, stereotypes and ethnicity, it has been resourcefully used in the ideological analysis of literary discourse.

Van Dijk's (2004) socio-cognitive framework comprises of two main discursive strategies "positive self-representation" and "negative other representation". Based on these two main strategies, several strategies and categories have been provided by this framework, which helps facilitating the process of analysing ideologies in different types of structures. Actor description is one of these strategies identified in Van Dijk's socio-cognitive framework. This strategy is concerned with the positive or negative way we describe actors or members of a particular society, which reflects our stand toward them. They are positively described if they are with us and negatively labelled if we oppose. This strategy includes several categories, including hyperbole, lexicalization, polarization, victimization, vagueness, categorization and comparison. These categories are mainly concerned with the positive and negative descriptions of those who are with us and those whom we oppose. The second strategy is resource description, which emphasizes that the conflicts arise when the access to resources is limited or threatened. In the context of this study, this strategy helps constructing the negative other through revealing how whiteness ideologies (e.g. whiteness as property) cause the conflict of interest between Blacks and Whites. The third strategy is self-identity descriptions, which is normally concerned with constructing the positive identity of threatened or marginalized groups. The fourth strategy is norm and value descriptions, which focuses on marginalized groups' emphasis of equality. It also emphasizes the other's violation of norms and values.

These discursive strategies and categories existing in Van Dijk's (2004) socio-cognitive framework contribute to the analysis of data in this study. They provide insights into the social reality created in Hughes' poetic discourse, which facilitates the interpretation of Hughes' discourse through deciding on Blacks' self-representation and the representation of other groups. These strategies also provide the linguistic analysis in this study with semantic, morphological and syntactic properties, which contributes to the revelation of ideological structures constructed in Hughes' poetic discourse. For instance, the negative and positive lexicalization of self and other contributes to constructing the representations of Whites and Blacks in Hughes' poetic discourse. The lexico-semantic structures help revealing Hughes' ideological structures of social reality, and therefore contribute to the revelation of Hughes' construction of whiteness and blackness. Through the positive-negative representation model, these strategies help disclosing the power relations between whiteness and blackness as viewed by Hughes.

\section{Method}

This study included 60 Hughes' poems (see Appendix A) that were purposively selected, which helped meeting the purpose of this study and answering its three questions. 


\subsection{Purposive sample}

In this study, the data were generated through purposive sampling. The sample in this study was not randomly selected; instead, the poems that represent the sample of this study were selected in accordance to their thematic subjects. In other words, the poems selected have been categorized as presenting certain themes, such as domination, segregation and discrimination. As pointed out by Patton (2002), the logic and power of purposive sampling depend on selecting information-rich cases for in-depth study. Selecting purposive sampling helped us understand the problem and enabled us to answer the research questions (Creswell, 2003). We selected 60 Hughes' poems which provide useful insights into the blackness and whiteness.

\subsection{Data collection and analysis}

Following Patton's (1990) six phases of thematic analysis, the codes, categories and themes were established. First, we started familiarizing ourselves with the data. The data were read deeply, and then notes were written in order to facilitate the process of coding. Initial codes were generated from the data. Table 1 shows examples of some initial codes generated from the data.

Table 1. Examples of data extracted and the initial codes for the data

\begin{tabular}{|ll|l|}
\hline \multicolumn{2}{|c|}{ Data extracted from Hughes' poems } & \multicolumn{1}{c|}{ Initial codes } \\
\hline 1 & Mr. President, sir, & Asking President \\
2 & I don't understand & Expressing no understanding \\
3 & Democracy that & Asking about Democracy \\
4 & Forgets the black man. & That does not include Blacks \\
(Extract 79 taken from Hughes' poem Dear Mr. President & \\
, Hughes, 1994, p.272) & \\
\hline
\end{tabular}

The initial codes were generated through analysing masses of data. In the third phase, different codes were organized in order to produce themes. After generating initial themes, these themes were reviewed. Coded data were examined to ensure that the initial themes could make patterns. Before producing the report, final themes were generated. Examples of final themes are shown in Table 2.

Table 2. Final themes from the coded data

\begin{tabular}{|ll|l|}
\hline \multicolumn{2}{|c|}{ Data extracted from Hughes' poems } & Initial themes \\
\hline 1 & White man & \\
2 & Makes me work all day & Economic power \\
3 & And I work too hard & \\
$4 \quad$ For too little pay- & \\
(Extract 31, taken from Hughes' poem Blue Bayou, & \\
Hughes, 1994, p.292) & \\
\hline $1 \quad$ They've just hung a black man & Racial power \\
$2 \quad$ In the dark of the moon. & \\
$3 \quad$ They've hung a black man & \\
$4 \quad$ To a roadside tree & \\
(Extract 94, taken from Hughes' poem Silhouette, & \\
Hughes, 1994, p.305) &
\end{tabular}

The themes were analysed and interpreted based on Van Dijk's perspective of CDA which serves as the theoretical framework of this study. The critical analysis focused on the syntactic features, lexicalization and semantics of the coded data. Rashid et al. (2016a) points out "the lexico-grammatical patterns which are prevalent in specialised texts constitute the construction of knowledge" (p. 184). The cognitive concepts within the coded data were examined, which helped revealing the discursive strategies deployed in constructing the themes. Attention was also given to the social structures emerged in the coded data. An example of Van Dijk's CDA is shown in Table 3. 
Table 3. Example of critical discourse analysis based on Van Dijk's framework

\begin{tabular}{|c|c|}
\hline Data extract & Critical discourse analysis \\
\hline $\begin{array}{l}\text { 1They've just hung a black man } \\
\text { 2In the dark of the moon. } \\
\text { 3They've hung a black man } \\
\text { 4To a roadside tree } \\
\text { 5In the dark of the moon } \\
\text { (Extract 94, taken from Hughes' } \\
\text { poem Silhouette, Hughes, 1994, } \\
\text { p.305) }\end{array}$ & $\begin{array}{l}\text {-Employing Van Dijk's (1998) polarized structure } \\
\text { (polarization) in the analysis of this extract } \\
\text {-The negative other they (lines } 1 \text { and } 3 \text { ) is } \\
\text { emphasized. } \\
\text {-Whites are constructed as devils because they } \\
\text { have hung that Black man at night. } \\
\text {-The pronoun they (lines 1and 3), which refers to } \\
\text { out-group, is negatively constructed in relation to } \\
\text { the lexical item hung (lines 1and 3). } \\
\text {-The lexical item hung (lines 1and 3) indicates } \\
\text { material process, which is associated with Whites. } \\
\text {-Whites are with agency that enables them to end } \\
\text { that Black man's life (lines 1-3). } \\
\text {-Their agency also occurs through their selection } \\
\text { of the time (lines } 2 \text { and 5) and place (line } 4 \text { ) of } \\
\text { execution. } \\
\text {-Blacks as victims of Whites' agency. } \\
\text {-Lynching is acted out of law, which reinforces } \\
\text { the power of Whites. }\end{array}$ \\
\hline
\end{tabular}

\section{Discussion and analysis}

What are the discursive strategies deployed in Hughes' poetic discourse? How do they contribute to the construction of whiteness and blackness? And how do they help constructing the power relations between Whites and Blacks? The analysis reveals that several discursive strategies have been utilized by Hughes in the process of constructing whiteness and blackness within his poetic discourse. The analysis also shows that these discursive strategies place emphasis on the positive-self and negative other-representations as well as the power relations between Whites and Blacks within the American context. Van Dijk's critical discourse analysis reveals that Hughes' poetic discourse constructs whiteness and blackness through the discursive strategies of actor description, resource description, selfidentity descriptions and norm and value descriptions. Table 4 shows emerging themes related to discursive strategies and their frequency. 
Table 4. Emerging themes related to discursive strategies and examples extracted from Hughes' selected poems

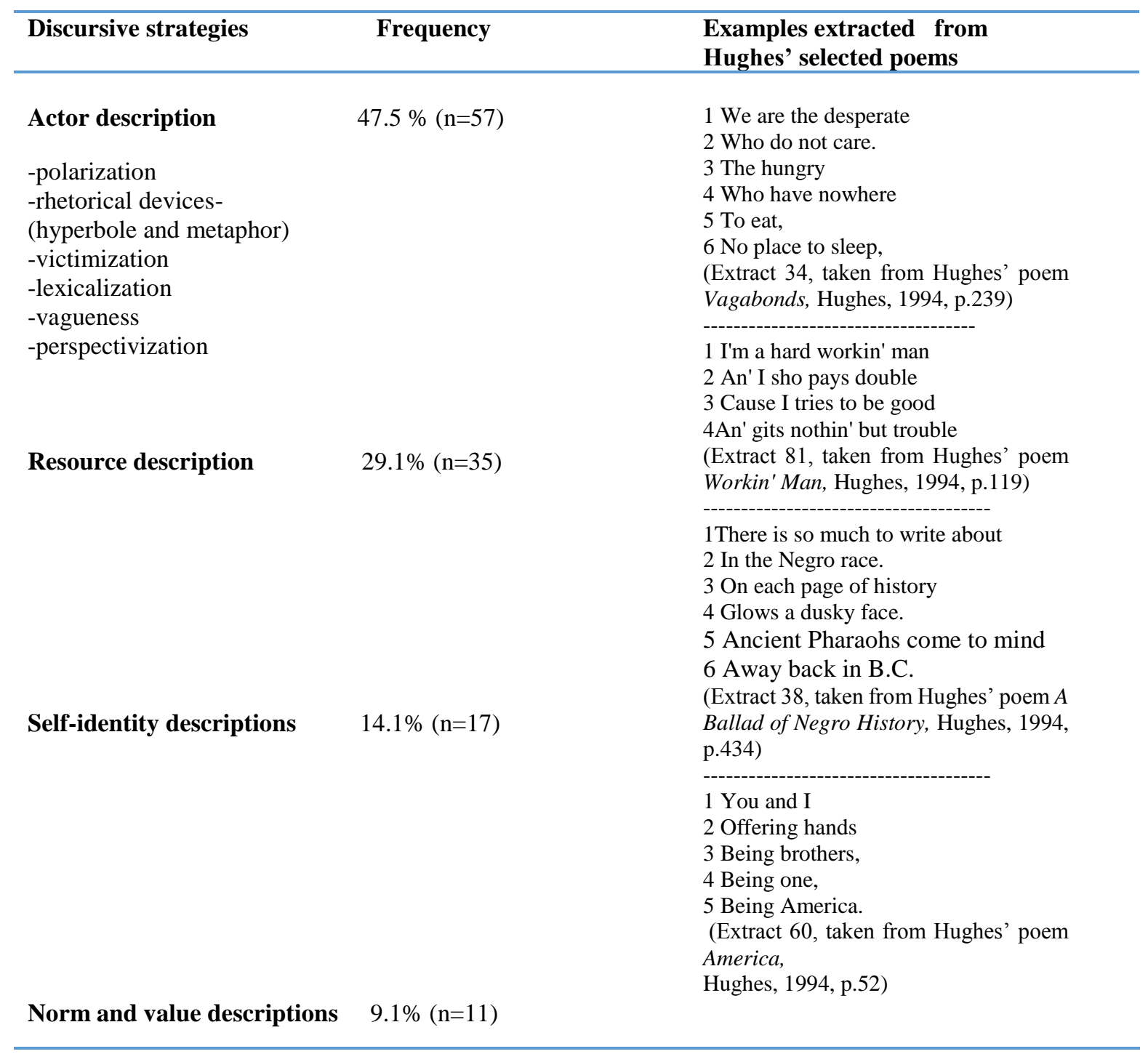

\subsection{The discursive strategies deployed in Hughes' poetic discourse}

Actor description makes the dominant discursive strategy utilized in Hughes' selected poems (see Table 4). As depicted in the example given (see Extract 34, Table 4), describing the 'social actors' (Van Dijk, 2004) that have been constructed by Hughes requires an examination of the ways those actors are referred to. In this extract, the 'perspectivization' (KhosraviNik, 2010, p.64) of Blacks is created through their naming as 'the desperate' and 'the hungry', which contributes to reflecting their position within social reality. Negative lexicalizations 'nowhere' and 'no place' and 'no care' moreover contribute to the perspectivization of Blacks. Furthermore, through the linguistic mechanism of 'aggregation' (KhosraviNik, 2010, p.64), Blacks are recognized as a group entity. Aggregation is created through the use of the pronoun We (line 1). With reference to Van Dijk's (2004) discursive strategy of polarization, the inclusive pronoun We (line 1) employed in this extract shows that these negative experiences are shared among the in-group members. Hughes' use of We (line 1) reflects his views as "belonging to the group who should have a say" (Rashid et al., 2016b, p. 76) about the negative experiences of Black people. Accordingly, Blacks' collective sense of desperation (line 1) is an immediate consequence for their lack of essentials. In a related vein, the presence of desperate Blacks as social actors without any 
reference to the social actors who cause their desperation and hunger leaves the extract with some vagueness. It is reasonable to suggest that this vagueness might have been intended by Hughes in order to give more focus on Blacks' experiences.

Bringing Blacks' terrible experiences and bad stories to poetic context resonates with in-group victimization (Van Dijk, 2004; Zulkffli \& Rashid, 2016; Ismail \& Al-Subaihi, 2020). This extract constructs Blacks as victims due to their deprivation of basic needs (e.g. food-lines 3-5 and housing-line 6). By featuring their negative experiences, Blacks are ceaselessly polarized, which contributes to constructing them as a powerless group, who cannot meet their basic needs. In this sense, the strong effect of racial ideologies is emphasized through the denial of Blacks' essentials. We argue that Blacks' social and economic exclusion could be an immediate consequence of whiteness ideologies that control the social reality. Having had no access to sources of production due to the huge influence of whiteness ideologies on social reality, this has contributed to decreasing Blacks' chances to access resources. In this sense, the unprivileged and victimized Blacks are positively represented whilst their victimizers are negatively considered.

The discursive strategy of resource description has also been employed in Hughes' poetic discourse, which contributes to the construction of whiteness and blackness. In the example shown (see Extract 81, Table 4), the image of Black man depicted by Hughes shows the negative impact of whiteness ideologies on his life. Thus, this Black man has been exploited by Whites, and so he works hard with no return (lines 1-4). We argue that whiteness ideologies (e.g. whiteness as property) contribute to constructing Black men as undesired employees, and thus this could explain the unfair pay to this Black man (lines 1-4). It is reasonable to suggest that Blacks' economic impairment resonates with Van Dijk's (1987, 2004) discursive ideology of resource description, which accentuates that the conflicts arise when the access to resources is limited or threatened. We argue that the interconnected relation emerged in Extract 81 between the instability of Blacks' economy (e.g. An' I sho pays double- line 2 and An' gits nothin' but trouble-line 4) and the ideologies related to racial and economic exploitation helps explaining how blackness turns Blacks inferior in a social reality dominated by whiteness ideologies. It is also important to notice that the conflict of interest has constructed Blacks as inferior and Whites as superior for the latter control the resources.

The third discursive strategy utilized in Hughes' discourse is self-identity descriptions. This strategy mainly contributes to creating positive self-identity, particularly for those groups whose identity is threatened or marginalized (Van Dijk's, 1987, 2004; Zaid et al., 2016). As pointed out by Van Dijk (2004), this strategy emphasizes the marginalized groups' properties, history and their difference from others. The main groups' features that are highlighted by this strategy are race, origin, culture, language and ethnicity. The example shown (see Extract 38, Table 4) evidences Hughes' ample interest in portraying the positive side of Blacks. In this extract, Hughes' emphasis of Blacks' place of origin and their rich culture seems clear. In this vein, Hughes' accentuation of Blacks' positive and superior culture is a direct response to the negative others' consideration of this culture as inferior. It is reasonable to notice that the positivity of clauses employed in this extract emphasizes the good self (e.g. Glows a dusky face-line 4 and Ancient Pharaohs come to mind-line 5). Moreover, the lexicalizations (e.g. each page of history-line 3, Ancient Pharaohs-line 5 and Away back in B.C-line 6) contribute to the construction of positive Blacks' culture and self-identity. We argue that this example evidences Hughes' high care of constructing Blacks' cultural cognition in the face of dominant White culture within the American context.

The final discursive strategy emerged in Hughes' selected poems and examined in this study is norm and value descriptions. According to Van Dijk (1987), this strategy places emphasis on the in-group's perceptions of good and bad and wrong or right. The strategy also focuses on in-group's goals to achieve. On the other hand, this strategy emphasizes the out-group's violation of norms and values. The given 
example (see Extract 60, Table 4) shows the ethnic groups' (Whites and Blacks) deliberate work to construct democratic America. The possible reason for presenting the polarized You and I (line 1) positively is that both groups seek to highly value cooperation (line 2), brotherhood (line 3) and oneness (line 4) (see Rashid et al., 2016c; Azizan, Ismail, Qaiwer, 2020). As shown in the extract, these common values are shared among all groups, which contribute to reinforcing the positive sense among all groups, and so a strong American society can emerge. We argue that this extract reflects Hughes' vision in that it emphasizes the significance of creating collective positive representations of all ethnic groups, which helps creating plural America.

\subsection{The construction of whiteness and blackness}

Drawing on the detailed analysis and interpretation set in 4.1, the four discursive strategies (actor description, resource description, self-identity descriptions and norm and value descriptions) manipulated in Hughes' poetic discourse contribute to the construction of whiteness and blackness through placing emphasis on the positive-self and negative other-representations. In this study, the critical analysis of data shows that Hughes' extensive use of linguistic properties (e.g. lexicalization and polarized structures) and cognitive concepts deeply related to the positive-self and negative otherrepresentations has largely contributed to the construction of whiteness and blackness. In this vein, it is reasonable to mention that Hughes' poetry constantly constructs whiteness negatively (e.g. Extracts 34 and 81, Table 4) for whiteness ideologies keep emphasizing the inferiority of blackness. As whiteness is considered a property, a lot of rights have been granted only to Whites, for instance, the right of possession (DeCuir \& Dixson, 2004). On the other hand, Hughes' poetry emphasizes the significance of blackness and positively portrays it. As shown in the analysis of data, inferior blackness has emerged as an immediate consequence for whiteness ideologies.

\subsection{The construction of power relations between Whites and Blacks}

Analysing the themes of power based on Van Dijk's perspective of CDA has contributed to the revelation of power relations between Whites and Blacks. The emerging themes reveal that power relations make the basis upon which whiteness and blackness have been constructed in Hughes' poetic discourse. In this vein, it is vital to notice that the social reality constructed in Hughes' discourse reflects the conflict of interests between Whites and Blacks, which contributes to creating positive-self (Hughes and Blacks) and negative other-representations (dominant groups, including Whites). As portrayed in a large number of selected poems in this study, blackness is often weakened and marginalized whilst whiteness is often portrayed as hegemonic. Indeed, the textual presentation mainly reflects the social reality experienced by Hughes himself. As shown in Table 5, the emerging themes from data analysis primarily revolve around power, including economic power, political power and racial power.

Table 5. Emerging themes related to power relations and examples extracted from Hughes' selected poems

\begin{tabular}{|c|c|c|}
\hline Themes & Frequency & $\begin{array}{l}\text { Examples extracted from Hughes' } \\
\text { selected poems }\end{array}$ \\
\hline $\begin{array}{l}\text { Economic power/Whites } \\
\text { and Blacks }\end{array}$ & $21.6 \%(n=26)$ & $\begin{array}{l}1 \text { You raise my taxes, freeze my wages, } \\
2 \text { Send my son to Vietnam. } \\
3 \text { You give me second-class houses, } \\
\text { (Extract } 113 \text {, taken from Hughes' The } \\
\text { Backlash Blues, Hughes, 1994, p.552) }\end{array}$ \\
\hline $\begin{array}{l}\text { Racial power/Whites } \\
\text { and Blacks }\end{array}$ & & $\begin{array}{l}\text { 1Being a colored man } \\
\text { 2Who looks like white, } \\
\text { 3He can go down South } \\
\text { 4Where a lynching takes place } \\
\text { 5And the white folks never }\end{array}$ \\
\hline
\end{tabular}


$42.5 \%(n=51)$

Political power/Whites

and Blacks

$28.3 \%(n=34)$
6Guess his race -

(Extract 45, taken from Hughes' Ballad

of Walter White, Hughes, 1994, p.567)

1Negroes never voted but

2Sam said, It's time to go

3To the polls election day

4And make your choice known

5 Cause the vote is not restricted

6To white folks alone.

(Extract 52, taken from Hughes' Ballad

of Sam Solomon, Hughes, 1994, p.295)

Economic power is a pattern or theme that has been revealed in the thematic analysis of selected data. As shown in the example (see Extract 113, Table 5), the economic power is a dominant theme in this extract. This theme has been constructed by Hughes' employment of two discursive strategies. The first one is actor description, where the polarized structure You, my and me (lines 1-3) dominates the entire extract. The aspects and processes related to social actors are also shown through perspectivization (pronouns- I, my and me-lines 1-3 and verbs of process-raise, freeze and give-lines 1-3). The verbs of processes show the economic power of Whites (lines 1 and 3). The second discursive strategy employed in this extract is resource description. The conflict between Whites and Blacks articulated in this extract is connected to economic issues. We argue that Whites' exercise of economic power over Blacks is due to the limitation of resources (e.g. raise my taxes and freeze my wages-line 1). In this vein, it is important to perceive how Whites' economic power contributes to emasculating Blacks and constructing their inferior blackness.

Another thematic point that has emerged from data analysis is racial power. Race proves to be highly significant in constructing whiteness and blackness. It decides on social actors' positions within the social reality. The example shown (see Extract 45, Table 5) evidences how race makes Whites privileged. The polarized structure constructed between the White folks (line 5) and a coloured man (line 1) shows that the power relations are mainly based on race. Hughes' placement of race at the centre of focus (Guess his race -line 6) in this extract gives evidence that whiteness ideologies control the social reality as these ideologies create Whites' power and keep Blacks inferior due to their race. In this extract, Whites are constructed as social actors and agents at the same time as they can lynch people of colour (line 4). As pointed out by McIntosh (1988), racial privilege supports Whites' gain simply because they are white in colour and at the same time leaves people of colour less privileged.

The analysis reveals that political power makes the third theme in Hughes' poetry. Whilst political rights are Whites' privilege, Blacks are deprived of these rights. The example (see Extract 52, Table 5) shows Blacks' struggle to gain their right to vote. It also reveals Whites' insistence to exclude Negroes from the whole political process (lines 5-6). We argue that Whites' assertion to exclude other groups from getting involved in political process helps Whites raise power. The conflicting interests (Negroes never voted- line 1) constructed among the social actors (Negroes and Whites) in this extract contribute to emasculating Blacks and empowering Whites. In this vein, it can be said that the power of whiteness is constructed through eliminating Blacks and refuting their civil rights. 


\section{Conclusions}

The discursive strategies of actor description, resource description, self-identity descriptions and norm and value descriptions developed in Hughes' poetic discourse contribute to the construction of whiteness and blackness within the American context. The strategies help placing emphasis on the positive-self and negative other-representations. In other words, they continually construct positive representations of Blacks whilst they develop negative representations of Whites. As revealed in the analysis of data, Whites and their whiteness ideologies are repetitively represented negatively as they contribute to emasculating Blacks and demeaning blackness. Moreover, the power relations between Blacks and Whites reflected in Hughes' discourse contribute to the construction of whiteness and blackness. Power relations are controlled by the interest of each group to grow power. This could explain the dominant groups' insistence on excluding other groups and denying their rights.

In this study, the emerging themes which are related to the discursive ideologies and power relations shed light on Hughes' depth of understanding the social reality. His reproduction of these highly complicated themes and real life experiences of his nation within his poetic discourse turns his poetry more functional than aesthetic. Though Hughes' poetic discourse is ideologically driven, it is still considered as simple discourse. The findings of this study show that Hughes constructs whiteness and blackness through bringing the positive and negative experiences of both Whites and Blacks to his poetic discourse. This reflects Hughes' high intellectuality as the interpretation of these constructs (whiteness and blackness) till now is at its infancy. As the findings of this study show three types of power emerging in this poetry, it is recommended that future research explores new types of power existing in this poetry. Future studies are also recommended to focus on the functional and aesthetic aspects of Hughes' poetry. Blacks' counter arguments and emancipating proposals are not within the scope of this study. Therefore, it is also advised that future research examines Blacks' emancipating proposals that aim at empowering blackness.

\section{Ethics Committee Approval}

The author(s) confirm(s) that the study does not need ethics committee approval according to the research integrity rules in their country.

\section{References}

Abed, K. Q., \& Mohammed, M. A. (2015). Transitivity as a means of communication: A stylistic study of Langston Hughes's selected early poems. International Journal of Multifaceted and Multilingual Studies, 1(VI), 1-16.

Azizan, M., Ismail, H. H., \& Qaiwer, S. N. (2020). Power and solidarity in positive Facebook postings amidst covid-19 in Malaysia. Journal of Nusantara Studies, 5(2), 329-364. https://doi.org/10.24200/jonus.vol5iss2pp329-364

Bhabha, H. K. (1998). The white stuff (political aspect of whiteness). Artforum International, 36(9), 21-23.

Case, K. A. (2012). Discovering the privilege of whiteness: White women's reflections on anti-racist identity and ally behavior. Journal of Social Issues, 68, 78-96. https://doi:10.1111/j.15404560.2011.01737.x

Cole, M. (2009). Critical race theory comes to the UK: A Marxist response. Ethnicities, 9(2), 246-269. https://doi.org/10.1177/1468796809103462 
Creswell, J. W. (2003). Research design: Qualitative, quantitative, and mixed methods approaches. (2 $2^{\text {nd }}$ ed.). Thousand Oaks, CA: Sage Publications.

DeCuir, J., \&Dixson, A. (2004). "So when it comes out, they aren't that surprised that it is there": Using critical race theory as a tool of analysis of race and racism in education. Educational Researcher 33(5), 26-31. https://doi.org/10.3102/0013189X033005026

Fanon, F. (1986). Black skin, white masks. London: Pluto.

Frankenberg, R. (1993). Introduction: Points of origin points of departure. In R. Frankenberg (Ed.), White women race matters: The social construction of whiteness (pp. 1-22). Minneapolis, MN: University of Minnesota Press.

Gohar, S. M. (2007). Dismantling the history of slavery and colonization in the poetry of Mohamed AlFayturi and Langston Hughes. Journal of Pan African Studies, 1(9), 151-169.

Hughes L. (1994). The collected poems of Langston Hughes. New York:Random House, Inc.

Ismail, H.H., \& Al-Subaihi, M.N. (2020). States of Malay powerlessness in the works of Che Husna Azhari. Journal of Nusantara Studies, 5(1), 211-233.

Johnson, P. (2003). Appropriating blackness: Performance and the politics of authenticity. Duke University press.

KhosraviNik, M. (2010). Actor descriptions, action attributions, and argumentation: Towards a systematization of CDA analytical categories in the representation of social groups, Critical Discourse Studies, 7(1), 55-72. https://doi.org/10.1080/17405900903453948

Mapedzahama, V., \& Kwansah-Aidoo, K. (2017). Blackness as burden? The lived experience of Black Africans in Australia. SAGE Open, 7(3), 1 -13. https://doi.org/10.1177/2158244017720483

Marriot, D. (2007). Haunted life: Visual culture and Black modernity. New Brunswick, NJ: Rutgers University Press.

McIntosh, P. (1988). White privilege and male privilege: A personal account of coming to see correspondences through work in women's studies. Retrieved from http://www.nymbp.org/reference/WhitePrivilege.pdf

Muslih, W. S. (2016). The Racial discrimination from romantic perspective: A postcolonial study of Langston Hughes's selected poems. AL-USTATH, 1(216), 11-22.

Patton, M. Q. (1990) Qualitative evaluation and research methods. Beverly Hills, CA: Sage.

Patton, M. Q. (2002). Qualitative research and evaluation methods. Thousand Oaks, CA: Sage.

Poongodi, A. (2012). An analysis of racial discrimination in Langston Hughes's selected poems. The Criterion: An International Journal in English, III(III), 1-4.

Rashid, R. A., Yunus, K., \& Wahab, Z. (2016a). Deconstructing functional organization of newspaper discourse. International Journal of Applied Linguistics \& English Literature, 5(6), 183-189.

Rashid, R. A., Wahab, Z., Yunus, K., Ismail, N. S., Yusof, N., Syed Omar, SNM., \& Latiff Azmi, M. N. (2016b). English language teachers as a dissenter on a social networking site. International Journal of Applied Linguistics \& English Literature, 5(4), 72-78.

Rashid, R.A., Yunus, K., Azmi, N.J., Safawati Basirah, Z., Rahman, S.B.A., \& Yusoff, S.Z. (2016c). The discursive construction of teachers' desirable identity on a social networking site. International Journal of Applied Linguistics and English Literature, 5(5), 139-144.

Reddy, B. S. (2013). Portrayal of racial-gender issues in the poems of Langston Hughes. Research Scholar, I(III), 1-4. 
Samaj, L. (1981). The Black self: Identity and models for a psychology of black liberation. Western Journal of Black Studies, 5(3), 158-171.

Sharma, A. K. (2017). Racial discrimination and protest in the poetry of Langston Hughes: A critical analysis. The Achievers Journal, 3(2), 21-38.

Sharma, L. R. (2018). Stylistic analysis of Langston Hughes's poem "Harlem". International Journal for Research in Educational Studies, 4(3), 1-10.

Stephane, B. Z. (2017). When Langston Hughes traduces the reflexive bad effects of white people's racism on black individuals who refuse "Feelin blue" in his poem "Bad man" or the blues poem. International Journal of Multidisciplinary Research and Development, 4(11), 96-106.

Van Dijk, T. A. (1987). Communicating racism: Ethnic prejudice in thought and talk. Newbury Park, CA: Sage Publications.

Van Dijk, T. A. (1995a). Aims of critical discourse analysis. Japanese Discourse, 1, 17-27.

Van Dijk, T. A. (1995b). Discourse analysis as ideology analysis. In C. Schaffner \& A. L. Wenden (Eds.), Language and peace (pp. 17-33). Dartmouth: Aldershot.

Van Dijk, T. A. (1997). Discourse as interaction in society. In T. A. Van Dijk (Ed.), Discourse as social interaction. Discourse studies: A multidisciplinary introduction (pp. 1-37). London: Sage Publications.

Van Dijk, T. A. (1998). Opinions and ideologies in the press. In B. Allan \& P. Garrett (Eds.), Approaches to media discourse (pp. 21-63). Oxford: Blackwell.

Van Dijk, T. A. (2001). Multidisciplinary CDA: A plea for diversity. In R. Wodak \& M. Meyer (Eds.), Methods of critical discourse (pp. 95-120). London: Sage Publications.

Van Dijk, T. A. (2004). Politics, ideology and discourse. Retrieved from http://wwww.discourse-insociety.org/teun.html

Yancy, G. (2008). Black bodies, white gazes: The continuing significance of race. Lanham, MD: Rowman \& Littlefield.

Zaid, S.B., Zakaria, M.H., Rashid, R.A., Ismail, N.S. (2016). An examination of negotiation process among ESL learners in higher institution. International Journal of Applied Linguistics and English Literature, 5(6), 228-234.

Zulkffli, M.A., \& Rashid, R.A. (2016). A discursive psychological analysis of Islamic sermons on homosexuality. International Journal of Applied Linguistics and English Literature, 5(6), 190-198.

\section{Appendix A}

The purposively selected poems in this study

\begin{tabular}{|l|l|}
\hline Laughers & Blue Bayou \\
\hline A Song to a Negro Wash-woman & Imagine \\
\hline Ruby Brown & Porter \\
\hline Madam and Her Madam & Vagabonds \\
\hline What? So Soon! & Memo to Non-White Peoples \\
\hline Beggar Boy & Circles \\
\hline Ma Man & Poem [1] \\
\hline The Negro Mother & A Ballad of Negro History \\
\hline West Texas & Freedom Train \\
\hline Black Gal & The Backlash Blues \\
\hline Red Silk Stockings & Bible Belt \\
\hline Midnight Dancer & Argument [2] \\
\hline & \\
\hline
\end{tabular}




\begin{tabular}{|l|l|}
\hline Mulatto & Flight \\
\hline Natcha & Workin' Man \\
\hline Only Woman Blues & Ballad of Walter White \\
\hline Early Evening Quarrel & Migration \\
\hline A Black Pierrot & Song of the Refugee Road \\
\hline Bad Man & The Bitter River \\
\hline Saturday Night & Seven Moments of Love \\
\hline Junior Addict & To Captain Mulzac \\
\hline Listen Here Blues & Black Workers \\
\hline Sailor & Ballad of Sam Solomon \\
\hline Barefoot Blues & Dear Mr. President \\
\hline Air Raid over Harlem & Beaumont to Detroit \\
\hline Little Song on Housing & Abe Lincoln \\
\hline Go Slow & Dream of Freedom \\
\hline Silhouette & The Mitchell Case \\
\hline Always the Same & The Kids in School with Me \\
\hline One-Way Ticket & We're All in the Telephone Book \\
\hline Who but the Lord? & America \\
\hline
\end{tabular}

\section{AUTHOR BIODATA}

Raed Awad Al-Ramahi is an instructor in the School of Languages, the University of Jordan. His research interests include critical discourse studies, sociolinguistics, and gender studies.

Radzuwan Ab. Rashid (Ph.D) is an Associate Professor in the Faculty of Languages and Communication, Universiti Sultan Zainal Abidin | UniSZA, Malaysia. His research focuses on sociocybernetics, discourse analysis, language education, and educational technology.

Omar Ali Al-Smadi (Ph.D) is an Assistant Professor in the Department of English Language, Al-Ghad International Colleges for Applied Medical Sciences. His areas of interests include applied linguistics, pragmatics, and sociolinguistics.

Hanita Hanim Ismail (Ph.D) is an Assistant Professor in the Faculty of Education, Universiti Kebangsaan Malaysia. Her research interests include issues of identity, ranging from religious to gender aspects. 